\title{
Merging wine and tourism-related services: evidence from the Douro (Portugal) Wine Region
}

\author{
Alexandre Guedes (iD) and João Rebelo (it) \\ Department of Economics, Sociology and Management (DESG), Centre for Transdisciplinary Development \\ Studies (CETRAD), University of Trás-os-Montes e Alto Douro, Vila Real, Portugal
}

\begin{abstract}
This article examines the supply structure and merging level of tourism-related services of wineries, focusing on a set of internal and external resources, namely corporate information, wine, tourism-related services/activities, information about the wine region inter-institutional network. A sample of 25 wine companies which own 103 wineries in the Douro Wine Region (DWR) are examined and enhanced with seven international wine regions as a benchmark. Results suggest that wineries exhibit an adaptive and atomized organization which is based on mutualistic cooperation between wine and tourism rather than being founded on a core product-supplementary services norm. The benchmarking analysis indicates that the parameters that define the online positioning of wineries in the DWR are in line with the best practices worldwide.
\end{abstract}

\section{ARTICLE HISTORY}

Received 5 August 2018

Accepted 13 April 2019

\section{KEYWORDS}

Wine tourism; winery; supply structure; symbiotic relationship; Douro region

\section{Introduction}

Wine tourism is regarded as a symbiotic phenomenon (Hall \& Mitchell, 2002; Mitchell \& Schreiber, 2006) which is based on a principle of mutualistic cooperation between wine and tourism. The way this relationship develops is reliant 'on a form of consumer behavior' (Getz \& Brown, 2006, p. 147) as well as on the strategy adopted by destinations to make use of and promote wine related assets within a leisure environment (Getz \& Brown, 2006). Wine tourism is also considered an opportunity for wine producing companies to bolster and sustain the wine economy by exposing and extending the rural system to a new environment, that is, tourism, which provides a 'low-cost distribution channel for the sale of wine' (Byrd, Canziani, Hsieh, Debbage, \& Sönmez, 2016, p. 19) as well as a 'marketing opportunity for wineries to educate, and to sell their products, directly to consumers' (Getz \& Brown, 2006, p. 147). To achieve this level of merging, wine regions and particularly wineries are progressively expanding tourist services and combining them to render wine a broader range of consumers as well as strengthen its perceived value (Gill, Byslma, \& Ouschan, 2007).

Grounded on the aforementioned development, Byrd et al. (2016) have applied the concept of supplementary services to wine tourism, circumscribing grape growing and wine production as the core service production circle separated from an array of 
supplementary services that have different peripheral values and which 'might be desired by the wine consumer or offered by the wine producer to enhance perceived benefits and product value' (Byrd et al., 2016, p. 22). Consequently, the supplementary services view is used to conceptualize wine region destination benefits based on a circle model where the inner core is comprised by wine which encapsulates both wine tasting and purchasing. The model further adds two circular layers as one moves to the outer shell which includes a middle ring comprised by augmented services (e.g. vineyard and landscape) and an outer ring which contains an array of ancillary services (e.g. hospitality services).

Wine tourism can also be construed as a composite phenomenon that has a systemic and functional nature, being 'composed of a set of elements interacting with each other and with the external environment in dynamic nonlinear ways' (Baggio \& Chiappa, 2017, p. 23) as well as contingent on demand-supply integration of the wine tourism experience (Hall et al., 2000). Thus, wine tourism is reliant on a collective commitment that goes beyond the strict limits of the agricultural economy (winery), namely grape growing and wine production, which deals with the concept of winescape (Hall et al., 2000; Nowak \& Newton, 2006; Peters, 1997), that overflows 'the core vineyard and/or winery' and expands into a more complex notion of a 'wine region as tourist destination' (Byrd et al., 2016, p. 20). This dimension requires a compromise of both private and institutional stakeholders involved, namely in the wine and tourism sectors.

Moreover, wine tourism transcends the ordinary visit to wineries or vineyards to buy or drink wine, providing a wider scope of benefits is perceived by consumers (Byrd et al., 2016). These include a variety of winery activities together with an extensive gamut of experiences and services both on and off site involving outdoor recreation, interaction with local culture, the discovery of nature, exploration of heritage and history, dining and lodging.

Extant literature has been focused on wine tourism demand, namely on motivating factors (Byrd et al., 2016) as well as on critical success attributes for wine tourism regions (Getz \& Brown, 2006) but scarce attention has been given to the analysis of the supply structure of wineries, in terms of merging wine marketing and tourism-related services, a gap this study tries to fulfil. However, the existing literature, namely on supplementary services, has advanced in modelling the relationship between wine production and tourism at a regional scale (wine tourism regions) and identified key internal and external resources that influence (and apply to) the supply structure of wineries, namely wine production, augmented services (vineyard, winemaking activity, and tasting rooms, wine education, and socializing/wine club offerings), ancillary services such as lodging, transportation services and visitor centres (Byrd et al., 2016) as well as pointing out the importance of institutional influence (Lavandoski, Pinto, Silva, \& Vargas-Sánchez, 2016).

Consistent with a holistic vision on wine tourism which lies in the definition of winescape, wine firms are interacting and communicating with consumers based on endemic and unique resources such as landscape, cultural and historical traits (Bruwer \& Alant, 2009), and thus positioning themselves in a global wine tourism market based on local destination attributes. Accordingly, the winescape's quality and its '(aesthetics) sense of place which presupposes some history' (Nohl, 2001, p. 225), intersects the sustainability matter, which has been recognized as a competitive advantage due to its ability to induce consumers, particularly within an international environment, to pay a premium price for a sustainable wine (Sellers-Rubio \& Nicolau-Gonzalbez, 2016). 
Additionally, wine producing companies seem to embrace tourism as an opportunity to amplify economic results which is symptomatically a 'contemporary rural restructuring' (Marsden, 2014, p. 23) trend, that has evolved to serve a consumption/tourism-oriented tendency by 'expanding the range of goods and services produced' (Menghini, 2015, p. 76) in response to 'diverse demands' (Marsden \& Murdoch, 1998, p. 1).

These arguments are in line with the management archetype of 'farmland diversification' (Marsden \& Sonnino, 2008, p. 423), which according to Gerowitt, Bertke, Hespelt, and Tute (2003) means that 'agricultural land use fulfils several functions' (p. 227), i.e. 'production, ecological, social and aesthetic' (p. 227), and that these utilities add to the farm's (in our case the winery's) income. This approach is interpreted as a replacement of the 'farm-based approach to the multifunctionality of agriculture' (Marsden \& Sonnino, 2008, p. 423), where agricultural production is at the core of the farm's economy.

Summing up, wineries can be theoretically approached from a 'resource dependence theory' perspective which describes the organization as an open system, by obtaining competitive advantage from the external environment (Hillman, Withers, \& Collins, 2009; Pfeffer \& Salancik, 2003), but also dependent upon their internal resources. Specifically, the winery's internal strengths combine the corporate's assets, (e.g. property, vineyards), the wine supply continuum and an internal supply chain which caters to tourism-related services/activities. The external environment encapsulates a set of resources which are outlined by regional contextual dimensions such as the wine region's cultural and historical attributes, that wineries can internalize as part of their supply assets. Another external dimension lies within the inter-institutional network that regards the level of functional integration of the winery with other stakeholders (public and private).

Thus, our study focuses purposely on internal and external resources, by looking into them from the winery's perspective, which Byrd et al. (2016) explicitly recommended. Findings from the winery's supply structure, which stem from the relation between wine and tourism, should provide entrepreneurs and policy-makers' tools for corporate governance and marketing decision making. More specifically, the aim is to provide empirical evidence of the winery's supply structure and level of merging of tourismrelated services, seeking to clarify if wine and tourism are two economic affiliates within the winery's economic structure, rather than tourism-related services playing a supplementary role.

In order to fulfil this goal, a regional case study was undertaken based on a sample of 25 wine producing companies in Portugal's Douro Wine Region (DWR), which is one of the oldest demarcated and regulated wine regions in the world (established in 1756) where the renowned Port wine is produced (Caldas \& Rebelo, 2013). Moreover, to strengthen the analysis and conclusions, we additionally examined the supply structure of a sample of wineries in seven international wine regions as a benchmark, following the same criteria applied to the DWR. This will allow an understanding of cross winery region differences and similarities as well as providing a framework that contributes to organizational improvement, namely of wineries, by observing comparable resources of the supply structure in some of the most relevant wine regions in the world.

The paper is organized as follows. The subsequent section presents an overview of wine and tourism in the DWR, the third provides a description of data collection, the fourth exposes and discusses the results and the final section concludes. 


\section{Wine and tourism in the Douro Wine Region}

Regardless of the long history and global notoriety of Port wine due to more than two centuries of being exported the DWR was almost undiscovered internationally until early 2000 (Rebelo \& Muhr, 2012). Several reasons contributed to the DWR's lack of international awareness, namely the fact that Port wine was predominantly related to big wine traders as well as the odd circumstance of it having been named after the Portuguese city of Porto from where it was shipped around the second half of the seventeenth century, which is located about $100 \mathrm{~km}$ west of the DWR.

Therefore, the emergence of the Douro as an international known wine producing region came late and it was due to the rise of new red still wines, the appellation d'origine contrôlée (AOC) Douro, a controlled designation of origin that explicitly indicates this region's name, and further stimulated by an innovative public relations strategy initiated in 2003 to position still wines in the global market. This effort began with an informal network of wine producers known as the Douro Boy's (Rebelo \& Muhr, 2012) which shortly after launching their public relations campaign to promote their wines achieved rapid international recognition. In the following years, the Douro's wines gained global appreciation being highly appraised by influential world wine reviewers (e.g. Robert Parker and Wine Spectator).

This prominent change together with the classification of the Alto Douro Wine Region (ADWR), (10\% of the DDWR), as World Heritage Site by the United Nations Educational, Scientific and Cultural Organization (UNESCO) (Rebelo, Caldas, \& Guedes, 2015) in 2001 caught the world's attention and triggered the emergence of tourism in the Douro, which also benefited from a considerable amount of direct governmental support (Andresen \& Rebelo, 2013). National policy clearly acknowledged the Douro's intrinsic attributes and its aptitude for tourism which helped to activate its global positioning as a sustainable destination. In 2010, National Geographic Society ranked the Douro in 7th place in the category of Best Rated Places among 133 destinations considering six criteria: '(1) environmental and ecological quality, (2) social and cultural integrity, (3) condition of historic buildings and archaeological sites, (4) aesthetic appeal, (5) quality of tourism management and (6) overall outlook for the future' (Hawkins, Chang, \& Warnes, 2009, p. 72).

Tourism has undoubtedly permeated the region and wineries (quintas), which are the main catalyst of the Douro's economy, (Rebelo, Guedes, Lourenço-Gomes, \& Sequeira, 2013), are at the forefront of the transformation. They have been looking for new marketing opportunities, specifically through tourism, by expanding new production segments to attract visitors (e.g. lodging and dining facilities) which add greater complexity to its value chain. This development trend allows us to postulate that the contemporary wineries' structure in the DWR seems to be dependent on a 'symbiotic relationship' (Hall \& Mitchell, 2002 , p. 69) between wine production and a wide gamut of tourism-related services as well as being grounded on a farmland diversification strategy.

\section{Data}

To investigate possible responses to our controlling hypothesis, that the winery's structure is based on 'symbiotic relationship' (Hall \& Mitchell, 2002, p. 69) between wine and tourism, we conducted a cross-sectional content analysis of wineries' websites during October 2017, from a group of 25 wine producing companies of reference, representing 
a total of 103 wineries (wine estates) of the DWR. The list of companies was extracted from a data base of wineries provided by the regional destination management organization (DMO) responsible for promoting the Porto and North of Portugal.

The sample is comprised of a diverse spectrum of firms ranging from family run wineries to large corporations which own more than 10 wineries (wine estates). Despite their dissimilar dimension and configuration, each company operates one winery as a visiting hub that provides wine tourism facilities and services. For this study's purpose, each one of these 25 wine producing companies' websites was surveyed to capture their supply structure and level integration of tourism-related services.

For the benchmarking analysis the selection of firms was defined according to a purposive sampling method and based on institutional and reference sources in the wine and tourism sectors (Figure 1) from which a total of 66 wineries were identified for analysis.

Based on the theoretical approach that assumes wine tourism as a systemic phenomenon, recognizing key multiple dimensions that outline the winery's supply structure as well as the implications of aesthetic elements in addition to the underlining importance of sustainability on wine tourism's development and the significance of the institutional influence on the provision of wine and tourism-related services, internal and external resources (Figure 2) that influence the winery's supply structure were surveyed.

Within the internal sphere, three groups of resources were examined which concern wine production and tourism-related activities that can have a positive impact on wine tourism by increasing the winery's global awareness, specifically: information about the property and company, focusing on supply resources such as the estate, viticulture, oenology, sustainability and people involved in the wine production process (IR.1); wine information, purposely focusing on wine characteristics, prizes and distribution systems (IR.2); and tourism-related services, which examined patterns of integration of tourism-related services/activities provided on and off premises (IR.3).

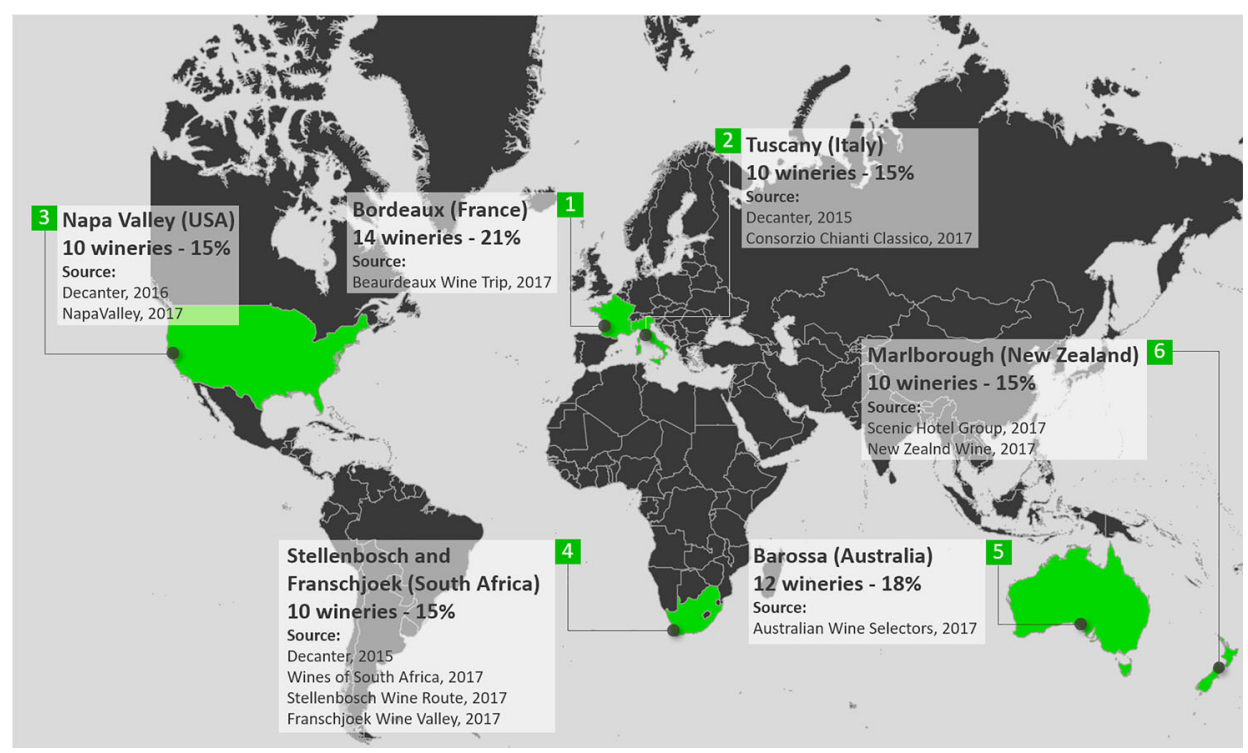

Figure 1. Regions and samples used for benchmarking analysis. 


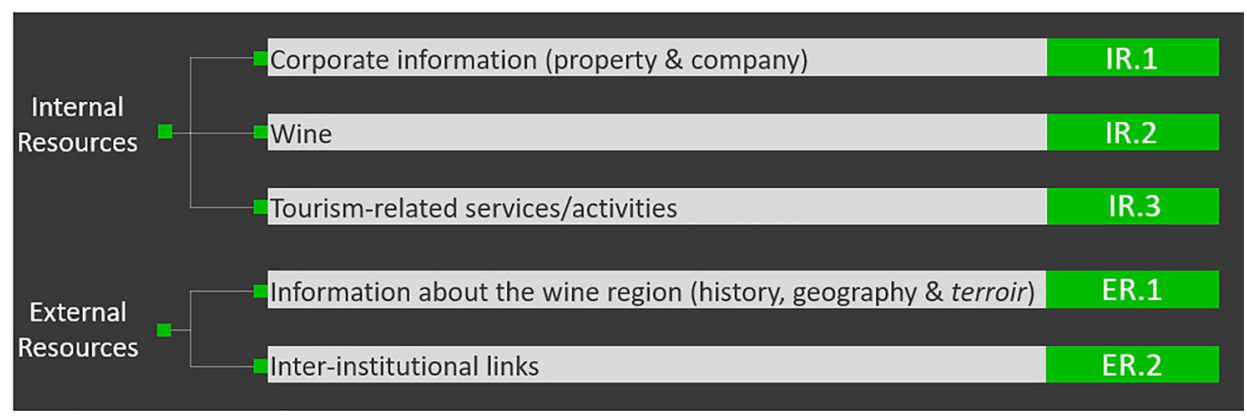

Figure 2. Internal and external resources.

In terms of the supply structure's external limits we considered two main topics: the winescape's features which convey the company's level of territorial immersion given the importance bestowed to the wine region's historical, geographical and terroir attributes (ER.1); and the inter-institutional linkage (ER.2) between wineries and national and regional organizations responsible for the wine and tourism sectors as well as other stakeholder links to determine the degree of systemic and functional integration of wineries into the tourism destination framework.

The next section provides an overview of the main results obtained from the DWR winery's supply analysis, according to both groups of resources, internal and external, and adds a third subset of results derived from the benchmarking analysis.

\section{Results}

\subsection{Wineries' supply structure in the DWR: internal resources}

The first group of internal resources (IR.1) focuses on corporate information. This topic, which was captured on $96 \%$ of wineries, concentrates on both property and ownership which are combined to generate a conspicuous identity and emphasize the distinctiveness of the wine brand. Firm's discourse revolves around land and its nature (e.g. location, altitude, total area, vineyard area, geological characteristics, etc.), extending the concept of terroir as an exercise of 'marketing strategy' (Guthey, 2008, p. 138), which can be understood as rhetorical cues intended to contextualize and induce latent wine consumers and visitors. This is also a key intangible dimension of the winery's supply structure that is meant to anticipate the consumer's/tourist's gaze allowing '(...) to see the physical forms and material spaces before their eyes as "interesting, good or beautiful"' (Urry \& Larsen, 2011, p. 2).

Moreover, communication underlines ownership which is imbued of 'personality traits of people related to the brand' that 'are transferred to the brand' (Heslop, Cray, \& Armenakyan, 2010, p. 293).

Corporate communication further emphasizes viticulture and oenology. Both wine production responsibilities disclose a personalized profile with references to the winemaker that seems to warrant the product's character and nature and convey credibility and value through technical knowledge and direct responsibility as well as involvement in the production process. 
Also, regardless of the importance of sustainability of the Douro Wine Region's landscape conservation (Lourenço-Gomes, Pinto, \& Rebelo, 2015), which stems from the Alto Douro Wine Region's classification as World Heritage Site by UNESCO, as well as the importance that this resource has acquired internationally with more wineries 'integrating sustainability into their communication strategy in an effort to reinforce their brand and market positioning' (Sellers-Rubio \& Nicolau-Gonzalbez, 2016, p. 96), only one company highlights this attribute, which reflects its present subsidiarity.

The second group of internal resources (IR.2) is characterized by a consistent pattern of concern to provide product information, namely associated with the wine's specificities. Thus, wine categories, brands and wine quality are regarded as critical marketing tools (referred by $100 \%$ of our sample) which are supplemented, when applicable, by awarded ratings of renown wine reviewers (e.g. Wine Spectator, Robert Parker, etc.), as a means of validating the wine's worth and quality. $84 \%$ (20) of wineries add technical files with the product's specifications, which convey the main oenological characteristics of wines. Despite the obvious effort to deliver and communicate the wine's value and distinct features, only $32 \%$ (8) of companies explain how to serve and drink their wines, which would add value and new commercial prospects, namely for companies which are engaged in Port Wine production, a highly complex product and referred to as excessively coded and veiled by Jorge Dias (Ferreira, 2018), which makes it difficult to communicate to new consumer segments. Explaining wine consumption, is a strategic instrument since wine is typically an experiential good, where quality can only be recognized after consumption (Caldas \& Rebelo, 2013). Thus, an effort to anticipate consumption's experience is a market advantage.

Regardless of wine's central role, merely eight wineries (32\% of our sample) possess an online direct sales system and just one firm used as marketing strategy to increase sales the Wine Club instrument, a direct selling method that is expected to produce higher gross margins (Newton, Gilinsky, \& Jordan, 2015) and encourage customer loyalty.

The third group of internal resources (IR.3) identifies patterns of integration of a wide gamut of tourism services and activities provided by the winery on and off premises, i.e. within and beyond the property. These are divided into five groups according to their frequency of provision: visits and tastings, onsite dining service, onsite accommodation, winery store and other tourism-related activities/services (Table 1).

Visits and tastings, which circumscribe the basic wine tourism activities, are provided by $92 \%$ (23) of companies. These constitute central elements of supply since they rely on a close connection with the wine product, both as a sensory experience and explanatory and interpretative event which takes place in tasting rooms. Additionally, visits and

Table 1. Tourism-related services/activities.

\begin{tabular}{lcc}
\hline & $\%$ & Wineries \\
\hline Visits and tastings & 92 & 23 \\
Onsite dining service & 64 & 16 \\
Onsite accommodation & 48 & 12 \\
Winery store $_{\text {Other tourism-related activities/equipments }}^{\mathrm{a}}$ & 32 & 8 \\
On Premises & - & - \\
Off Premises & 60 & 15 \\
\hline
\end{tabular}

${ }^{\mathrm{a} O r g a n i z e d ~ b y ~ t h e ~ w i n e r y . ~}$ 
tastings are arranged to allow visitors to acquire more knowledge on the production method and infrastructure by visiting both the winery's production facilities as well as the property and vineyards, which also offer an aesthetic experience of the winery.

In many cases, wineries in the Douro are providing high quality and sophisticated visitor infrastructures. A large amount of capital has been put into the contemporary architecture of renown architects such as Siza Vieira, a Pritzker Prize winner, to market the company and enhance the tourist experience by augmenting the interaction between production and visitors. This has been achieved through versatile and stimulating designed spaces that combine a variety of services (e.g. wine cellars, tasting rooms, and visitor centres).

Also noteworthy is the level of investment in hard tourism facilities which has been taking place in the last 15 years, particularly thrusted by the Portuguese government's support for the development of tourism in the Douro (Rebelo et al., 2013), showcased in $48 \%$ of our sample's companies which possess a lodging establishment on premises and $64 \%$ which provide a dining facility (e.g. restaurant) (Table 1).

This level of integration of the winery's economy generates additional sources of income and promotes a new incremental selling channel for wine. It likewise acts as a marketing and branding tool by construing a new, glamorous and in some cases a cuttingedge image to the consumer.

A recurrent characteristic which is noticeable is that a relevant portion (80\%) of wineries which possess a lodging establishment are equally owners of dining facilities. This should not be unrelated to the spatial pattern of the Douro valley, which is morphologically dominated by vineyards and mountainous topography, raising complex issues related to accessibility which influence the dispersion of services and namely shortage of dining services.

Results also show that wine stores are not considered a crucial feature of supply since it was captured in no more than $32 \%$ of our sample's wineries.

The remaining internal supply components include a wide variety of services/activities directly organized by the company in and off the property (e.g. picnics, walking and bicycle tours, bird watching, fishing programmes, etc.). Some wineries have evolved to cater remarkable and innovative services such as organized walking trails within the winery's vineyards.

Surprisingly, the provision of traditional activities with a high experiential impact, which fall within 'other tourism-related services/activities' organized on premises, such as harvesting and crushing grapes by foot, have a residual reference, amounting, respectively, to $12 \%$ ( $20 \%$ of on premises services/activities) and $20 \%$ (33\% of on premises services/ activities) of the study's sample.

\subsection{Wineries' supply structure in the DWR: external resources}

The first group of external resources (ER.1) examined the winescape's features that are imbued within the winery's online discourse. We searched for pivotal references regarding the terroir, history and geography of the DWR which reflect the winery's level of territorial immersion and the intention to capture the 'aesthetic cognition' (Nohl, 2001) of visitors that are sensitive to different levels of knowledge about the wine region (e.g. perceptual, expressive, symptomatic and symbolic) (Nohl, 2001). These attributes were acknowledged in $48 \%$ (12) of companies which take advantage of the DWR being one of the oldest demarcated and regulated wine regions in the world. Thus, a relevant portion of our 
sample's wineries are sensitive to aesthetic dimensions which constitute the winery's surrounding environment - the 'wine tourist terroir' (Hall et al., 2000, p. 9), which acts as a cultural lens (Urry \& Larsen, 2011) to persuade prospective consumers to buy wine and visit the winery.

The second group of external resources (ER.2) probed the length of external institutional relations, namely the interconnections between wine and tourism public organizations, as well the amount of integration of offsite activities depending on reliable functional integration of other destination stakeholders. Observations show that just three companies provide external corporate governance evidence using hyperlinks to institutional websites which reveals asymmetrical relations, as well as shortage of shared relevant information about the destination for visitors/consumers. An improved external corporate correlation would amplify the economic impact of wine tourists both in the winery and in the region.

Tourists and wine producing companies would benefit from a regional systemic and functional governance approach that enables access to relevant information concerning key destination features such as transportation system, things to see, that would increase the winery's sustainability as well as the Douro region as a whole.

Furthermore, firms which supply hyperlinks to institutional websites in both wine and tourism sectors uncover a misalignment of both sectors which do not share the same promotional strategy to guide wine tourism in the Douro region. This is a key component of wine tourism development since 'institutional environment exerts pressure on the behaviour of wineries toward wine tourism development' (Lavandoski et al., 2016, p. 266).

We also captured a slight level ( $32 \%$ of our sample) of functional articulation with complementary sectors which provide offsite activities such as walking tours, boat tours, train tours, and golf. There is still much room for improvement in view of its residual reference and potential to reduce seasonality and increase the length of stay.

\subsection{Benchmarking assessment based on seven wine regions}

As a means of assessing the DWR wineries' positioning at a global scale a benchmarking analysis was applied, considering as reference seven world renown wine-growing regions (Tuscany - Italy, Bordeaux - France, Napa Valley - USA, Barossa - Australia, Stellenbosch and Franschjoek - South Africa and Marlborough - New Zealand). Observations indicated that (Table 2): (a) the parameters that define the online positioning of the wineries in the Douro region are in line with the best practices; (b) sustainability is highly regarded as a distinctive feature in Napa Valley considering that $80 \%$ of the sample's companies explicitly refer this feature as a benefit do the consumer, which is clearly an outcome of a regional strategy to promote sustainable wine-growing practices within the California wine industry however, this attribute is not unanimous around the world, as happens in the Douro region, wineries in Bordeaux award a residual reference to this feature; (c) Napa Valley stands out for its consistent trust in the Wine Club strategy to foster consumer loyalty ( $100 \%$ of companies analysed), which is similarly replicated in Australia and New Zealand; (d) an average of $90 \%$ of all companies surveyed in our sample in the New World use online direct sales tools (Table 2) in contrast with the Douro's sample where the online sales system was identified in $32 \%$ of wineries' websites; likewise, in both Old World wine regions, Bordeaux and Tuscany, the online sales system is marginally 
Table 2. Benchmarking summary.

\begin{tabular}{|c|c|c|c|c|c|c|c|}
\hline & \multicolumn{3}{|c|}{ Old World } & \multicolumn{4}{|c|}{ New World } \\
\hline & $\begin{array}{c}\text { Douro } \\
(\%)\end{array}$ & $\begin{array}{l}\text { Tuscany } \\
\text { (\%) }\end{array}$ & $\begin{array}{l}\text { Bordeaux } \\
\text { (\%) }\end{array}$ & $\begin{array}{c}\text { Napa } \\
\text { Valley } \\
(\%)\end{array}$ & $\begin{array}{c}\text { Barossa } \\
(\%)\end{array}$ & $\begin{array}{l}\text { Stellenbosch and } \\
\text { Franschhoek (\%) }\end{array}$ & $\begin{array}{l}\text { Marlborough } \\
\text { (\%) }\end{array}$ \\
\hline Sustainability (b) & 4 & 40 & 14 & 80 & 33 & 30 & 40 \\
\hline Wine club/Membership (c) & 4 & 10 & 0 & 100 & 67 & 30 & 60 \\
\hline Online selling system (d) & 32 & 10 & 21 & 90 & 100 & 90 & 80 \\
\hline Visits and tastings (e) & 92 & 80 & 93 & 100 & 92 & 90 & 100 \\
\hline Onsite dining services (e) & 64 & 60 & 29 & 20 & 50 & 60 & 40 \\
\hline Onsite accommodation (e) & 48 & 60 & 21 & 0 & 33 & 20 & 30 \\
\hline Winery store $(f)$ & 32 & 40 & 21 & 90 & 100 & 90 & 70 \\
\hline \multicolumn{8}{|l|}{$\begin{array}{l}\text { Other tourism-related } \\
\text { services/equipments }^{\mathrm{a}}(\mathrm{g})\end{array}$} \\
\hline On Premises & 60 & 60 & 50 & 80 & 58 & 50 & 50 \\
\hline Off Premises & 20 & 0 & 0 & 0 & 0 & 0 & 20 \\
\hline $\begin{array}{l}\text { Information about the } \\
\text { region }(\mathrm{h})\end{array}$ & 48 & 0 & 0 & 0 & 25 & 0 & 0 \\
\hline sample & 25 & 10 & 14 & 10 & 12 & 10 & 10 \\
\hline
\end{tabular}

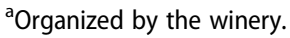

employed by wineries ( $21 \%$ and $10 \%$, respectively); (e) the supply construct of wineries exhibits a wider range of tourist activities and services which include visits and tastings, onsite accommodation and dining facilities; ( $f$ ) on average, $88 \%$ of wineries in the New World possess a wine store, a pattern which diverges from the Old World's wineries where this item was identified in $31 \%$ (average) of subjects; $(\mathrm{g})$ the DWR reveals, on a formal level, a diversity of activities in and off the winery, which individually denotes a reasonable functional and territorial integration; (h) provision of information about the region is much higher in the DWR than in the wine-growing regions that were analysed abroad. Except for one case in the USA, none of the observed wineries provided any information about their respective wine region, which may reveal that the historical length and traits of the DWR may be more culturally entrenched and constitute an element of territorial and cultural cohesion as well as an attribute that authenticates wines in a global environment.

\section{Discussion}

This research's results provide a cross-sectional picture of the DWR's supply structure that captures its complementary construct which is grounded on a purposeful symbiotic and synergetic link between wine and tourism. Results clearly exhibit a development drive which is based on a 'farmland diversification' model, where each production utility adds to the winery's income rather than being based on a supplementary archetype where tourism activities play an ancillary role. The observed wineries exhibit a supply structure which is shaped by several internal and external resources who perform (wine) production, social, environmental, aesthetic and recreational functions.

Thus, our results extend previous research outcomes namely of Byrd et al.'s (2016) supplementary model by displaying the importance of each added internal and external supply component that fulfils singular but also complementary functions.

The symbiotic and synergetic link between wine and tourism is a structural measure that is pushing the winery's supply structure in the DWR towards sectorial diversification 
which is purposefully engaged in providing strategic mediation of seasonality fluctuations in the wine production cycle. This is achieved by enhancing internal resources and providing, in many cases, onsite accommodation and dining services, as well as a wide gamut of activities that can also take place all year round. Thus, the managerial archetype is efficiency-led, and tourism is a key tool to increase wine direct sales, enhance the bottle of wine's value (Carlsen, 2004), diversify income sources and mediate the wine production cycle's seasonality.

We can allow the argument that, although wine production is unequivocally a relevant economic factor, tourism is clearly a strategic economic affiliate comprised by an array of new production elements that add greater complexity to the winery's value chain. Results visibly acknowledge that the contemporary winery's supply structure in the DWR is more complex than it was at the beginning of this century, which was considered incipient according to Ribeiro and Marques (2002).

Additionally, while wine tourism in the DWR is grounded on a set of diverse wine firms, ranging from companies which have invested in hard tourism products/services such as lodging and dining establishments within the winery, to smaller and family run firms, in either cases they reveal greater diversity of activities in and off the winery which individually denotes a reasonable functional integration with other service providers in the region.

Thus, results exhibit the importance of external resources which extend the boundary of the supply's dynamics beyond the winery (property) (Figure 3), similarly taking advantage of a symbiotic relationship between wine and tourism within the broader context of the winescape. This is also evidence that wineries in the DWR acknowledge the need of a systemic approach towards wine tourism (as a phenomenon) to steer the wine region's tourism purpose.

The external resources' results provide evidence concerning systemic engagement which involves the articulation of key destination resources such as network transportation system, things to see, etc., which are missing from a considerable amount of wine producing companies' communication. This could be an outcome of negligible

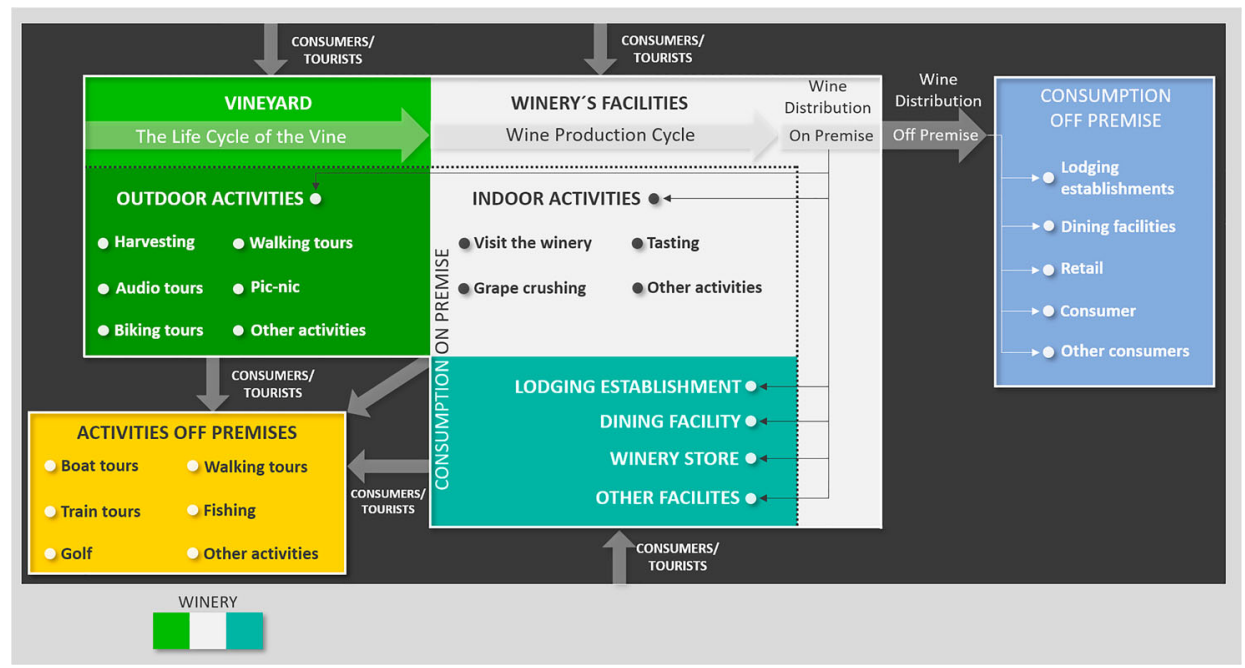

Figure 3. Schematic illustration of the DWR's winery productive model. 
inter-institutional linkage between wineries and national and regional organizations responsible for the wine and tourism sectors.

Perfecting these interconnections could enhance the degree of functional integration of the wineries within the Douro region as a wine tourism destination. An improved external corporate correlation, as well as articulated institutional strategy between wine and tourism sectors, could help develop a full awareness amongst wine firms and regional stakeholders to establish the region's positioning as a wine destination. This could enable a brand identity that 'in turn can and should be linked to a marketing strategy of branding the region' (Bruwer \& Lesschaeve, 2012, p. 625).

Despite the overall positive supply structure and development status of the DWR's wineries, benchmark results exhibit some critical features that could have a positive impact on wine tourism in the Douro region by increasing global awareness of wines and brands. These features are fundamentally restricted to marketing tools, specifically online selling systems, the Wine Club sales channel as well as the winery store, which are highly valued in New World wine regions. The Wine Club is particularly interesting since its objective is to increase the company's profitability based on loyal customers which are less price sensitive. Although this is clearly perceived by wineries in most New World wine regions, and particularly in the USA, as a strategic means to collect consumer data in order to derive preferences (e.g. red or white wines; varieties) (Santini, Faraoni, \& Zampi, 2008) it is poorly understood in the Old World wine regions and particularly in the Douro region which could be due to the average size of producers as well as shipping logistics. Also, the winery store, which is a direct sales mechanism that enhances product differentiation as well as experiential benefits, is underdeveloped in the Old World wine regions in comparison to New World wine regions. In the particular case of the Douro, despite being one of the oldest wine regions in the world, the low percentage of winery stores (32\%) is mostly linked to the recent development, in the early 2000s, of new still wines with the appellation d'origine contrôlée Douro, which is gradually enabling more small producers to invest in winery stores (Rebelo \& Hogg, 2018).

\section{Conclusion}

This empirical research article sought to apprehend the contemporary winery's supply structure in the DWR and evaluate the level of merging of tourism-related services based on an online survey of wine producing companies. Results confirmed that the supply configuration of wineries in the DWR displays a symbiotic interaction between wine production and integrated tourism-related services in response to various demands. This means that despite wine production's significance due to its various layers of value and output (wine, landscape, etc.), wineries exhibit an adaptive and atomized organization that is co-evolving according to the developing corporate strategy, which is based on a mutualistic cooperation between wine and tourism by merging both activities rather than being established on a principle of a core product and supplementary services.

Furthermore, the benchmarking analysis exhibits some of the Douro's limitations which fall within the scope of marketing. These include the minimal use of the Wine Club instrument that can induce customer loyalty as well as the lack of use of sustainability as a benefit to consumers and a price premium factor. 
From a theoretical perspective, this paper builds on Byrd et al.'s (2016) model which looks at consumer motivating attributes grounded on a supplementary services theory to attain de main extent of the winery's supply structure. It also picks up on institutional theory (e.g. Lavandoski et al., 2016) to construe the set of inter-institutional features as well as sustainability issues that take part and influence the winery's supply structure. Overall, this paper expands the aforementioned theory by adding new knowledge on wine tourism and offering a novel view of the interconnections between resources within wine and tourism-related services at the winery business level. It also provides specific evidence on the winery's supply structure in the DWR and articulates this analysis with a broad and global view of the same resources by looking into seven world renown wine-growing regions as a benchmark.

As a result, this research also delivers practical managerial contributions by providing a template of resources that can support managers' assessment of both wine and tourism utilities at the winery business level. Furthermore, the study delivers useful managerial guidelines that rationalize the winery's supply dynamics which depend on internal components, but also require responsiveness towards a range of external elements, such as local suppliers, institutional players alongside with shared natural resources.

The study also provides a useful analytical overview of wine tourism in the DWR based on the winery's standpoint. This will allow entrepreneurs and policy-makers to articulate and tighten marketing strategies to strengthen the wine destination's global awareness. This study exhibits systemic flaws in terms of functional merging that need improvement. Specifically, the institutional environment as a measure of compliance with the objective towards the development of the DWR as a wine tourism destination is absent from the entrepreneurial ecosystem. Also, and despite some interesting examples, there is clear space for a sounder articulation between wineries and other destination stakeholders to capture new consumer segments. Likewise, wineries in the DWR need to shorten the gap with the best international practices, namely in terms of sustainability driven consumer view.

Despite this research's analytical and qualitative perspective on wine tourism and its intent to understand the supply structure of wineries, it has inherent limitations due to the predictive restrictions of cross-sectional studies. It does not capture time effects, namely the evolution of the Douro Wine Region's wineries supply dynamics over time and the corresponding impact of change in both wine and tourism utility functions. Furthermore, the use of surveys applied to both the winery's owners/managers and regional stakeholders should take place in future research to robust this study's results and capture prospective evidence on managerial, marketing and governance strategies which impact on the winery's supply construct. Further research should also focus on critical issues revealed by the benchmarking analysis which exhibits the uneven role of stores and Wine Clubs across wine regions.

\section{Acknowledgments}

The authors would like to thank the anonymous reviewers for their helpful and constructive comments that greatly contributed to improving the quality of this paper.

\section{Disclosure statement}

No potential conflict of interest was reported by the authors. 


\section{Funding}

This work was supported by the project NORTE-01-0145-FEDER-000038 (INNOVINE \& WINE - Innovation Platform of Vine \& Wine) and by European and Structural and Investment Funds in the FEDER component, through the Operational Competitiveness and Internationalization Programme (COMPETE 2020) [Project No 006971 (UIC/SOC/04011)].

\section{ORCID}

Alexandre Guedes (i) http://orcid.org/0000-0003-2019-3535

João Rebelo (i) http://orcid.org/0000-0003-3564-7771

\section{References}

Andresen, T., \& Rebelo, J. (2013). Avaliação do Estado de Conservação do Bem Alto Douro Vinhateiro Paisagem cultural Evolutiva Viva, Volume 1 - Relatório de Avaliação. Porto: CIBIO UP/UTAD.

Australian Wine Selectors. (2017, March 9). WineSelectors. Check out the best Barossa Valley Wineries. Retrieved from https://www.wineselectors.com.au/selector-magazine/wine/the-best-barossavalley-wineries

Baggio, R., \& Chiappa, G. D. (2017). Complex tourism systems: A quantitative approach. In M. Uysal, Z. Schwartz, \& E. Syrakaya-Turk (Eds.), Management science in hospitality and tourism: Theory, practice and applications (pp. 21-42). Oakville: Apple Academic Press.

Bordeaux Wine Trip. (2017). Bordeaux vineyards and wineries. Retrieved from https://www. bordeauxwinetrip.com/What-to-see-do/Wineries.

Bruwer, J., \& Alant, K. (2009). The hedonic nature of wine tourism consumption: An experiential view. International Journal of Wine Business Research, 21(3), 235-257.

Bruwer, J., \& Lesschaeve, I. (2012). Wine tourists' destination region brand image perception and antecedents: Conceptualization of a winescape framework. Journal of Travel \& Tourism Marketing, 29(7), 611-628.

Byrd, E., Canziani, B., Hsieh, J., Debbage, K., \& Sönmez, S. (2016). Wine tourism: Motivating visitors through core and supplementary services. Tourism Management, 52, 19-29.

Caldas, J., \& Rebelo, J. (2013). Portuguese wine rating: An old product a new assessment. Wine Economics and Policy, 2, 102-110.

Carlsen, J. (2004). A review of global wine tourism research. Journal of Wine Research, 15(1), 5-13.

Consorzio Chianti Classico. (2017). Aziende. Retrieved from http://www.chianticlassico.com/aziende/

Decanter. (2015, December 2). Stellenbosch and Franschhoek: Wineries to visit. Retrieved from http://www.decanter.com/wine-travel/south-africa/stellenbosch-and-franschhoek-wineries-tovisit-284034/

Decanter. (2015, July 24). Ultimate Tuscany: Top 10 wineries to visit. Retrieved from http://www. decanter.com/wine-travel/italy/top-10-tuscan-wineries-to-visit-13770/2/

Decanter. (2016, February 4). 10 top California cellar doors. Retrieved from http://www.decanter.com/ wine-travel/10-top-napa-valley-wineries-to-visit

Ferreira, A. (2018, February 22). Vinho do Porto. A queda do império francês. Expresso. Retrieved from http://expresso.sapo.pt/economia/2018-02-22-Vinho-do-Porto.-A-queda-do-imperio-frances\#gs. tXT9Kns

Franschjoek Wine Valley. (2017). Wineries. Retrieved from http://franschhoek.org.za/vignerons-defranschhoek/

Gerowitt, B., Bertke, E., Hespelt, S. K., \& Tute, C. (2003). Towards multifunctional agriculture - weeds as ecological goods? Weed Research, 43, 227-235.

Getz, D., \& Brown, G. (2006). Critical success factors for wine tourism regions: A demand analysis. Tourism Management, 27, 146-158.

Gill, D., BysIma, B., \& Ouschan, R. (2007). Customer perceived value in a cellar door visit: The impact on behavioural intentions. International Journal of Wine Business Research, 19(4), 257-275. 
Guthey, G. (2008). Agro-industrial conventions: Some evidence from northern California's wine industry. The Geographical Journal, 174(2), 138-148.

Hall, C., Johnson, G., Cambourne, B., Macionis, N., Mitchell, R., \& Sharples, L. (2000). Wine tourism: An introduction. In C. M. Hall, L. Sharples, B. Cambourne, \& N. Macionis (Eds.), Wine tourism around the world: Development, management and markets (pp. 1-23). Oxford: Butterworth-Heinemann.

Hall, C., \& Mitchell, R. (2002). The touristic terroir of New Zealand wine: The importance of region in the wine tourism experience. In A. Montanari (Ed.), Food and environment: Geographies of taste (pp. 69-91). Rome: Societa Geografica Italiana.

Hawkins, D., Chang, B., \& Warnes, K. (2009). A comparison of the national Geographic Stewardship Scorecard ratings by experts and stakeholders for selected World Heritage destinations. Journal of Sustainable Tourism, 17(1)), 71-90. doi:10.1080/09669580802209944

Heslop, L., Cray, D., \& Armenakyan, A. (2010). Cue incongruity in wine personality formation and purchasing. International Journal of Wine Business Research, 22(3), 288-307.

Hillman, A., Withers, M., \& Collins, B. (2009). Resource dependence theory: A review. Journal of Management, 35(6), 1404-1427.

Lavandoski, J., Pinto, P., Silva, J., \& Vargas-Sánchez, A. (2016). Causes and effects of wine tourism development in wineries. International Journal of Wine Business Research, 28(3), 266-284.

Lourenço-Gomes, L., Pinto, L., \& Rebelo, J. (2015). Wine and cultural heritage. The experience of the Alto Douro Wine Region. Wine Economics and Policy, 4, 78-87.

Marsden, T. (2014). Economic perspectives. In B. Ilbery (Ed.), The geography of rural change (pp. 1330). New York, NY: Routledge.

Marsden, T., \& Murdoch, J. (1998). The shifting nature of rural governance and community participation. Journal of Rural Studies, 14(1), 1-4.

Marsden, T., \& Sonnino, R. (2008). Rural development and the regional state: Denying multifunctional agriculture in the UK. Journal of Rural Studies, 24, 422-431.

Menghini, S. (2015). The new market challenges and the strategies of the wine companies. Wine Economics and Policy, 4, 75-77.

Mitchell, R., \& Schreiber, C. (2006). Barriers to vertical integration between the wine and tourism industries: The case of Central Otago, New Zealand. Paper presented at 3rd International Wine Business Research Conference, Montpellier, 6-8 July. Manuscript in preparation. Retrieved from http:// academyofwinebusiness.com/wp-content/uploads/2010/05/Mitchell.pdf

NapaValley. (2017). Napa Valley wineries. Retrieved from https://www.napavalley.com/businesses/? category=Wineries

Newton, S., Gilinsky, A., \& Jordan, D. (2015). Differentiation strategies and winery financial performance: An empirical investigation. Wine Economics and Policy, 4, 88-97.

New Zealand Wine. (2017). Marlborough wineries. Retrieved from https://www.nzwine.com/en/ourregions/marlborough/marlborough-wineries/

Nohl, W. (2001). Sustainable landscape use and aesthetic perception-preliminary reflections on future landscape aesthetics. Landscape and Urban Planning, 54(1-4), 223-237.

Nowak, L., \& Newton, S. (2006). Using the tasting room experience to create loyal customers. International Journal of Wine Marketing, 18(3), 157-165.

Peters, G. (1997). American winescapes: The cultural landscapes of America's wine country. Boulder, CO: Westview Press.

Pfeffer, J., \& Salancik, G. (2003). The external control of organizations: A resource dependence perspective. Stanford, CA: Stanford University Press.

Rebelo, J., Caldas, J., \& Guedes, A. (2015). The Douro region: Wine and tourism. Almatourism - Journal of Tourism, Culture and Territorial Development, 6(11), 75-90. doi:10.6092/issn.2036-5195/4647

Rebelo, J., Guedes, A., Lourenço-Gomes, L., \& Sequeira, M. (2013). Balanço da Concretização do Programa de ação. In T. Andresen, \& J. Rebelo (Eds.), Avaliação do Estado de Conservação do Bem Alto Douro Vinhateiro - Paisagem cultural Evolutiva Viva, Volume 2 - Estudos de base (pp. B3/01-B3/77). Porto: CIBIO UP/UTAD.

Rebelo, J., \& Hogg, T. (2018). Rumo Estratégico para o setor dos vinhos do Porto e Douro. ed. 150, 1 vol., ISBN: 978-989-704-344-4. Vila Real: Universidade de Trás-os-Montes e Alto Douro. 
Rebelo, J., \& Muhr, D. (2012). Innovation in wine SMEs: The Douro Boys informal network. Studies in Agricultural Economics, 114, 111-117.

Ribeiro, M., \& Marques, C. (2002). Rural tourism and the development of less favoured areas? Between rhetoric and practice. International Journal of Tourism Research, 4, 211-220.

Santini, C., Faraoni, M., \& Zampi, V. (2008). Wine clubs as marketing tool for segmenting customers, building winery loyalty and image: Some empirical evidence. In R. Moliterni (Ed.), 11th ToulonVerona international conference on quality in services: Higher education, health care, local government, tourism, banking. Paper presented at University of Florence, Dipartimento di Scienze Aziendali, 4-5 September (pp. 575-592). Firenze: Firenze University Press.

Scenic Hotel Group. (2017). Top 10 wineries to visit in Marlborough. Retrieved from https://www. scenichotelgroup.co.nz/locations/new-zealand/blenheim/scenic-hotel-marlborough/regionalinfo/top-10-wineries-to-visit-in-marlborough

Sellers-Rubio, R., \& Nicolau-Gonzalbez, J. L. (2016). Estimating the willingness to pay for a sustainable wine using a Heckit model. Wine Economics and Policy, 5, 96-104.

Stellenbosch Wine Route. (2017). Wineries. Retrieved from http://www.wineroute.co.za/member/

Urry, J., \& Larsen, J. (2011). The tourist gaze 3.0. London: SAGE. 